\title{
Binding of a radioiodinated 13-azapinane thromboxane antagonist to platelets: correlation with antiaggregatory activity in different species
}

\author{
Shuh Narumiya ${ }^{1}$, Minoru Okuma \& Fumitaka Ushikubi \\ Department of Medical Chemistry and Department of Internal Medicine, Kyoto University Faculty of \\ Medicine, Sakyo-ku, Kyoto 606, Japan
}

1 Binding of a ${ }^{125} \mathrm{I}$-labelled derivative of the 13-azapinane thromboxane antagonist (ONO-11120), [ $\left.{ }^{125} \mathrm{I}\right]-9,11$-dimethylmethano-11,12-methano-16-(3-iodo-4-hydroxyphenyl)-13,14-dihydro-13-aza-15$\beta$ - $\omega$-tetranor-thromboxane $A_{2}$ ([25I]-PTA-OH), to washed platelets of human, dog and rabbit was studied. Results were compared with the in vitro inhibitory potency of ONO-11120 on platelet aggregation induced by arachidonate and a thromboxane agonist, 9,11-epithio-11,12-methanothromboxane $\mathbf{A}_{2}\left(\mathbf{S T A}_{2}\right)$.

$\left.2{ }^{125} \mathrm{I}\right]-\mathrm{PTA}-\mathrm{OH}$ bound to washed human platelets in a reversible, saturable and temperaturedependent manner, and specific binding displaced by $20 \mu \mathrm{M}$ ONO-11 120 constituted about $40 \%$ of the total binding. Scatchard analyses revealed a single class of specific binding and the equilibrium dissociation constant $\left(K_{\mathrm{D}}\right)$ and maximal concentration of binding sites $\left(B_{\max }\right)$ were $22 \mathrm{nM}$ and $390 \mathrm{fmol}$ per $10^{8}$ platelets (about 2,300 sites per platelet), respectively. In addition to ONO-11120, STA 2 and another thromboxane receptor agonist, (15S)-hydroxy-11,9-epoxymethano-prosta-5Z,13E-dienoic acid (U-46619), effectively displaced the binding with $\mathrm{IC}_{50}$ values of 44 and $125 \mathrm{nM}$ respectively. Prostaglandin $\mathrm{D}_{2}\left(\mathrm{PGD}_{2}\right)$ partially displaced the binding only at a concentration above $1 \mu \mathrm{M}$. $\mathrm{PGE}_{1}$ and thromboxane $\mathrm{B}_{2}\left(\mathrm{TXB}_{2}\right)$ were without effect up to $100 \mu \mathrm{M}$.

3 Similar binding of [ $\left.{ }^{125} \mathrm{I}\right]-\mathrm{PTA}-\mathrm{OH}$ was observed on dog platelets. The $K_{\mathrm{D}}$ and $\boldsymbol{B}_{\max }$ were $12 \mathrm{nM}$ and $110 \mathrm{fmol}$ per $10^{8}$ platelets (about 680 sites per platelet), respectively, and these values did not change significantly after adrenaline treatment which potentiated arachidonate-induced aggregation of platelets in this species. On the other hand, no specific binding of [ $\left.{ }^{125} \mathrm{I}\right]-\mathrm{PTA}-\mathrm{OH}$ was found on rabbit platelets.

4 Consistent with the results from binding studies, ONO-11120, $0.5 \mu \mathrm{M}$, completely suppressed arachidonate-induced aggregation of human platelets, whereas, at concentrations up to $5 \mu \mathrm{M}$, this agent did not significantly inhibit aggregation of rabbit platelets induced by the same stimulus. STA $\mathbf{A}_{2}$ induced aggregation of rabbit platelets also showed less sensitivity to ONO-11120. When a similar extent of irreversible aggregation was induced by STA $\mathrm{A}_{2}$ and the inhibitory potency of ONO-11120 was compared in human and rabbit platelets, about one hundred times greater concentration of ONO11120 was required to suppress aggregation of rabbit platelets than that of human platelets.

5 These results suggest that [ $\left.{ }^{125} \mathrm{I}\right]-\mathrm{PTA}-\mathrm{OH}$ binds to a platelet thromboxane receptor, and that the structure of the binding site(s) on the receptor may vary between species.

\section{Introduction}

Thromboxane $A_{2}\left(T_{X A}\right)$, a major cyclo-oxygenase metabolite of arachidonic acid in platelets (Hamberg et al., 1975), is a most potent stimulator of platelet aggregation and constrictor of vascular as well as other smooth muscle (Svensson et al., 1976; 1977).

'Author for correspondence. Present address: Dept. of Pharmacology, Kyoto University, Faculty of Medicine, Sakyo-Ku, Kyoto 606, Japan.
Since this compound is very unstable and its chemical synthesis has only recently been achieved (Bhagwat $e t$ al., 1985), various stable analogues to mimic its actions have been synthesized and used as tools to study the effects of TXA $_{2}$ in various systems. These include endoperoxide analogues such as $9,11-$ or 11,9-epoxymethano-prostaglandin $\mathrm{H}_{2}$ (11,9-epoxymethano-

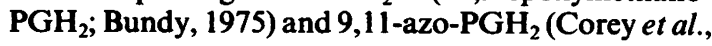


1976), and TXA analogues such as CTA $\mathrm{A}_{2}$ (Lefer et al., 1980) and 9,11-epithio-11,12-methano-TXA (STA $_{2}$; Katsura et al., 1983), in which oxygen atoms in the endoperoxide or acetal structure are replaced by other atoms.

Using these TXA $_{2}$ mimetics and enzymatically generated $\mathrm{TXA}_{2}$, a variety of compounds which antagonize the actions of $\mathrm{TXA}_{2}$ have also been developed. These include 13-azaprostanoic acid (Le Breton et al., 1979), pinane thromboxane $\mathrm{A}_{2}\left(\mathrm{PTA}_{2}\right)$ (Nicolaou et al., 1979), AH-19437 ([1 $\alpha(\mathrm{Z}), 2 \beta, 5 \alpha]-$ methyl 7-[2-(4-morpholinyl)-3-oxo-5-(phenylmethoxy)cyclopentyl]-5-heptenoate, Coleman et al., 1981) and a 9,11-ethano- $\mathrm{PGH}_{2}$ analogue with a phenylsemicarbazone chain, EP-045, (Jones et al., 1982). ONO-11120 (9,11-dimethylmethano-11,12-methano16-phenyl)-13,14-dihydro - 13 - aza - $15 \alpha \beta-\omega$-tetranor$\mathrm{TXA}_{2}$ ) recently developed by Katsura et al. (1983) has structural features of both 13-azaprostanoic acid and PTA $_{2}$ (13-azapinane TXA 2 derivative) and shows selective antagonism against $\mathrm{STA}_{2}$ and 11,9-epoxymethano-PGH ${ }_{2}$ in various systems (Katsura et al., 1983). Using these compounds, several groups have analysed the actions of TXA ${ }_{2}$ on platelets and vascular as well as tracheal smooth muscles. These studies have suggested that $\mathrm{TXA}_{2}$ acts on a putative membrane receptor(s) to elicit its action, and based on different responsiveness of various systems to these compounds, multiplicity and differences in TXA 2 receptors in various tissues and between species have been discussed (Lefer et al., 1980; Jones et al., 1982; Burke et al., 1983; Parise et al., 1984; Armstrong et al., 1985; Mais et al., 1985a).

As for biochemical characterization of $\mathrm{TXA}_{2}$ receptor(s), several groups using radiolabelled analogues as radioligands have carried out binding studies in human platelets or platelet membranes, and have found binding activities, presumed to be putative $\mathrm{TXA}_{2}$ receptor(s), on human platelets (Hung et al., 1983; Armstrong et al., 1983; Halushka et al., 1985). Although these binding studies have clarified several important properties of the platelet $\mathbf{T X A}_{2}$ receptor, especially as regards the specificity of binding and its correlation with biological activities, there are some discrepancies among the studies. These mainly concern the numbers of binding components and the density of binding sites on platelets, and may be resolved by using other ligands.

In this study, we prepared the radioiodinated hydroxy derivative of ONO-11120 ([125 I]-PTA-OH) by the method recently described by Mais et al. (1984), and characterized the $\mathbf{T X A}_{2}$ receptor on human platelets with this ligand. We further compared this binding activity with the antiaggregatory activity of ONO-11120 in platelets of different species, and examined the heterogeneity of the platelet $\mathbf{T X A}_{2}$ receptor in various species.

\section{Methods}

\section{Binding studies}

Blood was collected, by venipuncture from human volunteers and rabbits and by carotid artery cannulation from dogs anesthetized with pentobarbitone, into one-tenth volume of $3.8 \%$ trisodium citrate and centrifuged at $180 \mathrm{~g}$ for $10 \mathrm{~min}$ to prepare platelet-rich plasma (PRP). One-tenth volume of $77 \mathrm{mM}$ sodium EDTA, pH 7.4, was added to PRP, and the mixture was centrifuged at $1,200 \mathrm{~g}$ for $10 \mathrm{~min}$. The platelet pellet was washed once with the washing buffer (composition, mM: $\mathrm{NaCl} 135, \mathrm{KCl} 5, \mathrm{Na}_{2} \mathrm{HPO}_{4} 8$, $\mathrm{NaH}_{2} \mathrm{PO}_{4} 2$ and EDTA 10, pH 7.2), and recentrifuged. The platelets were finally suspended in the suspension buffer (composition, $\mathrm{mM} \mathrm{NaCl} 138, \mathrm{MgCl}_{2}$ 5, EGTA 1 and Tris-HCl 25, pH 7.5) at a density of $10^{9}$ platelets per $\mathrm{ml}$.

Binding studies were performed by incubating $10^{8}$ platelets with $0.1 \mathrm{nM}\left[{ }^{125} \mathrm{I}\right]-\mathrm{PTA}-\mathrm{OH}$ in a total volume of $200 \mu \mathrm{l}$ in a $1.5 \mathrm{ml}$ Eppendorf tube at $37^{\circ} \mathrm{C}$. Nonspecific binding was obtained by displacing bound radioactivity with $20 \mu \mathrm{M}$ ONO-11120. The reaction

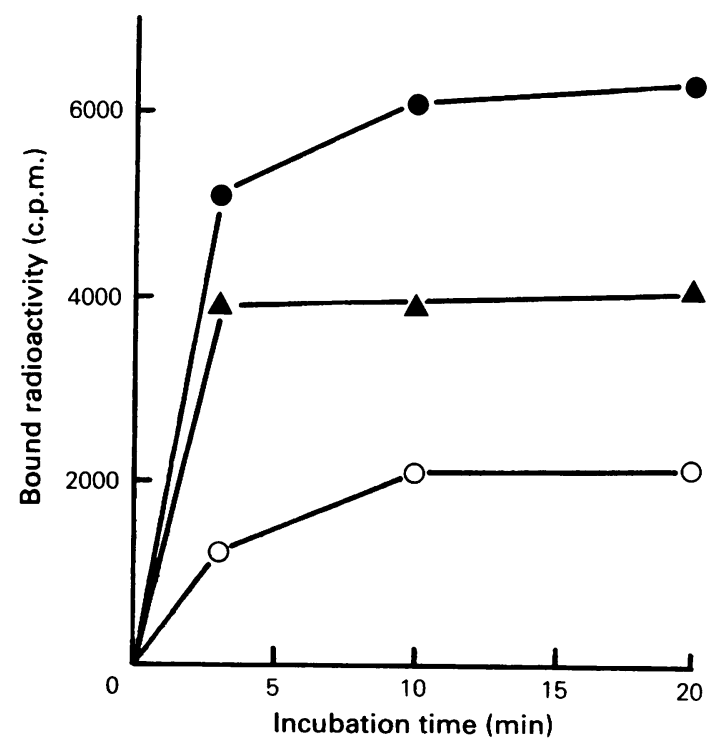

Figure 1 Time course of $\left.\left[{ }^{125}\right]\right]-P T A-O H$ binding to washed human platelets. [ $\left.{ }^{125} \mathrm{I}\right]-\mathrm{PTA}-\mathrm{OH}, \quad 20 \mathrm{fmol}$ $\left(40,000\right.$ c.p.m.), was incubated with $10^{8}$ washed human platelets in $200 \mu$ l of the suspension buffer at $37^{\circ} \mathrm{C}$. Total binding (O) was obtained as described in Methods. Nonspecific binding $(\Delta)$ was determined by including $20 \mu \mathrm{M}$ ONO-11120 in the incubation mixture, and the specific binding $(O)$ was calculated by subtracting non-specific binding from total binding. This figure is a typical record from one of seven similar experiments. Each point was measured in duplicate, and the mean is shown. 
was terminated by centrifuging the tubes in an Eppendorf centrifuge at $15,000 \mathrm{~g}$ for $2 \mathrm{~min}$. The supernatant was rapidly removed with a Pasteur pipette, and the pellet washed with $1 \mathrm{ml}$ of the suspension buffer. The radioactivity in the pellet was measured on a Packard Automatic 460C Scintillation System by the use of Gamma-vial type C (G \& G Chemicals \& Service Ltd, Berks.). When displacement of bound radioactivity by $\mathrm{TXA}_{2}$ mimetics was studied in human platelets, $50 \mathrm{nM}$ $\mathrm{PGD}_{2}$ was added to the reaction mixture to prevent aggregation.

\section{Platelet aggregation}

Platelet aggregation was studied nephelometrically as described previously (Yoshimoto et al., 1977) with a slight modification. PRP $(200 \mu$ l) was continuously stirred in a tube and the increase in light transmission was followed by a dual-channel aggregometer NKK Hema Tracer 1 model PAT-2A (Niko Bioscience, Tokyo, Japan) at $37^{\circ} \mathrm{C}$. Aggregating agents used were arachidonic acid, STA 2 and U-46619. Arachidonic acid was dissolved in $0.1 \mathrm{M} \mathrm{Na}_{2} \mathrm{CO}_{3}$ and $\mathrm{STA}_{2}$ in $0.9 \%$ $\mathrm{w} / \mathrm{v} \mathrm{NaCl}$ solution (saline) to appropriate concentrations before use. U-46619 and ONO-11120 were stored in $10 \mathrm{~mm}$ ethanol solution and diluted with saline before use. Final concentrations of ethanol in PRP were always below $0.10 \%$. ONO- 11120 was added $1 \mathrm{~min}$ prior to the addition of the aggregating agent being studied.

\section{Compounds}

ONO-11120, $\mathrm{PGD}_{2}, \mathrm{PGE}_{2}, \mathrm{TXB}_{2}$ and $\mathrm{STA}_{2}$ were kindly donated by Ono Pharmaceuticals. U-46619 ((15S)-hydroxy-11,9-epoxymethano-prosta-5Z,13Edienoic acid) was a gift from Dr J. Pike, the Upjohn Company. The hydroxy derivative of ONO-11120, 9,11-dimethylmethano-11,12-methano-16-(4-hydroxyphenyl)-13,14-dihydro-13-aza-15 $\beta-\omega$-tetranor-TXA (PTA-OH), was a gift from Dr Hamanaka of Ono Central Institute, and radioiodination of this compound with ${ }^{125}$ I was carried out by Amersham International plc; the specific activity was $2,000 \mathrm{Ci} \mathrm{mmol}^{-1}$. The compound was stable at $-20^{\circ} \mathrm{C}$ for at least two months. Arachidonic acid was purchased from $\mathrm{Nu}$ Check Prep. (Elysien, MN, U.S.A.). Adrenaline was obtained from Daiichi Seiyaku Ltd (Tokyo, Japan).

\section{Statistical analyses}

Results, when appropriate, are expressed as mean\pm s.e.mean. Statistical analyses were made by means of Student's $t$ test, when variances of two groups were equal. When variances were unequal, Tukey's method was used after one-way analysis of variance (Wallenstein et al., 1980).

\section{Results}

\section{Binding of $\left[^{125} I\right]-P T A-O H$ to washed human platelets}

Incubation of washed human platelets with $0.1 \mathrm{nM}$ $\left[{ }^{125} \mathrm{I}\right]-\mathrm{PTA}-\mathrm{OH}$ resulted in binding of a considerable amount of radioactivity to platelets. Figure 1 illustrates the time course of binding at $37^{\circ} \mathrm{C}$. The total binding reached equilibrium within $10 \mathrm{~min}$ at this temperature, and remained at the same level for up to $20 \mathrm{~min}$ of the incubation. When $20 \mu \mathrm{M}$ ONO-11120 was included in the incubation mixture, the total binding was inhibited by approximately $30-40 \%$, and the difference between the total and remaining binding represent displaceable 'specific' binding of [ [25 I]-PTA$\mathrm{OH}$. The specific binding was reversible, since a similar extent of displacement was observed by adding $20 \mu \mathrm{M}$ ONO-11120 after the binding had reached equilibrium. In one experiment, the total binding of 5,125 c.p.m. per $10^{8}$ platelets at equilibrium decreased to $3,288,2,874,2,668$ and 2,540 c.p.m. per $10^{8}$ platelets at $3,9,15$ and $20 \mathrm{~min}$ after the addition of $20 \mu \mathrm{M}$ ONO11120 , respectively (mean values of duplicates are shown; typical results from one of three similar experiments). With decreases in incubation temperature, the velocity of binding decreased and equilibria were not reached within $20 \mathrm{~min}$ at 4 and $20^{\circ} \mathrm{C}$. The total binding at 4 and $20^{\circ} \mathrm{C}$ was 33 and $65 \%$ of that at $37^{\circ} \mathrm{C}$ at $10 \mathrm{~min}$, respectively, and the displaceable binding at these temperatures was 25 and $28 \%$ of the respective total binding. The binding was linear with platelet number up to $2 \times 10^{8}$ platelets per incubation medium (Figure 2). A saturation curve for



Figure 2 Specific $\left[{ }^{125} \mathrm{I}\right]-\mathrm{PTA}-\mathrm{OH}$ binding to washed platelets from human, dog and rabbit. [ $\left.{ }^{125} \mathrm{I}\right]-\mathrm{PTA}-\mathrm{OH}$, $0.1 \mathrm{nM}$, was incubated with various numbers of washed platelets obtained from human $(O), \operatorname{dog}(O)$ and rabbit (D) at $37^{\circ} \mathrm{C}$ for $20 \mathrm{~min}$, and specific binding was determined as described. A typical results of one of three similar experiments. Each point represents the mean of duplicate measurements. 

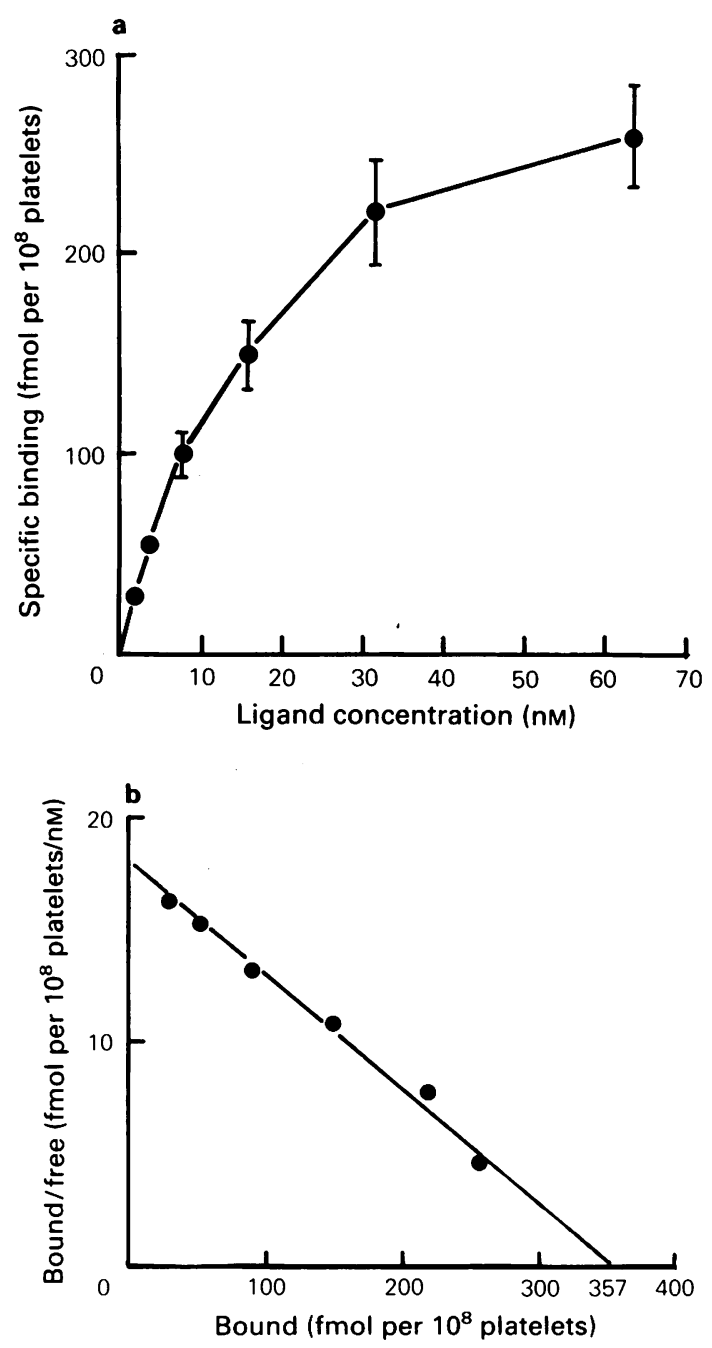

Figure 3 (a) Saturation of the specific $\left[{ }^{125} \mathrm{I}\right]-\mathrm{PTA}-\mathrm{OH}$ binding to washed human platelets. Washed human platelets, $10^{8}$, were incubated with $0.1 \mathrm{nM}\left[{ }^{125} \mathrm{I}\right]-\mathrm{PTA}-\mathrm{OH}$ in the presence of various concentrations $(2,4,8,16,32$ and $64 \mathrm{nM}$ ) of $\mathrm{ONO}-11120$ at $37^{\circ} \mathrm{C}$ for $20 \mathrm{~min}$, and the specific binding was determined by displacing with $20 \mu \mathrm{M}$ ONO-11120. Mean values are shown; s.e.mean is shown by a vertical line when it exceeds the size of a symbol. $n=5$. (b) Scatchard plot of the specific $\left[{ }^{125} \mathrm{I}\right]-\mathrm{PTA}-\mathrm{OH}$ binding to washed human platelets. Each point represents the mean of five experiments shown in (a).

$\left[{ }^{125} \mathrm{I}\right]-\mathrm{PTA}-\mathrm{OH}$ specific binding is shown in Figure 3a. The specific binding tended to saturate at a ligand concentration of around $70 \mathrm{nM}$. The Scatchard analysis of this binding yielded a straight line, indicating a single class of binding sites for [ $\left.{ }^{125} \mathrm{I}\right]-\mathrm{PTA}-\mathrm{OH}$
(Figure 3b). The equilibrium dissociation constant $\left(K_{\mathrm{D}}\right)$ and the maximal concentration of [ $\left.{ }^{125} \mathrm{I}\right]-\mathrm{PTA}-\mathrm{OH}$ binding sites $\left(B_{\max }\right)$, as determined by Scatchard analysis, gave values of $22.1 \pm 2.3 \mathrm{nM}$ and $392 \pm 37 \mathrm{fmol}$ per $10^{8}$ platelets $(2360 \pm 220$ sites per platelet), respectively $(n=7)$. Hill coefficient $(n)$ of the binding was 0.989 , indicating a single homogeneous class of the binding sites without cooperativity.

To evaluate the specificity of this binding, ONO11120 and two thromboxane mimetics, STA $A_{2}$ and $U-$ 46619 , as well as other prostaglandins and $\mathrm{TXB}_{2}$ were added to the incubation mixture and their potencies in displacing [ $\left.{ }^{125} \mathrm{I}\right]-\mathrm{PTA}-\mathrm{OH}$ binding were compared. As shown in Figure 4, [225 I]-PTA-OH binding was effectively displaced by the two TXA $\mathrm{T}_{2}$ mimetics, STA $\mathrm{S}_{2}$ and $\mathrm{U}-46619$, at submicromolar concentrations. The $\mathrm{IC}_{50}$ values for ONO-11120, STA 2 and U-46619 were $19.6 \pm 4.0(n=4), 43.8 \pm 7.5(n=4)$, and $125 \pm 17$ $(n=3) \mathrm{nM}$, respectively. The $\mathrm{IC}_{50}$ for $\mathrm{STA}_{2}$ was significantly lower than that for U-46619 $(P<0.05$, Student's $t$ test). PGD $_{2}$ displaced [ ${ }^{125}$ I]-PTA-OH binding in a concentration-dependent manner at concentrations greater than $1 \mu \mathrm{M}$. However, displacement by this prostaglandin was limited to about $70 \%$ of that by the $\mathrm{TXA}_{2}$ analogues and complete displacement was not achieved at $100 \mu \mathrm{M} . \mathrm{PGE}_{1}$ and $\mathrm{TXB}_{2}$ were without effect at concentrations up to $100 \mu \mathrm{M}$ (data not shown).



Figure 4 Displacement of the specific $\left[{ }^{125} \mathrm{I}\right]-\mathrm{PTA}-\mathrm{OH}$ binding by various compounds. Washed human platelets, $10^{8}$, were incubated with $0.1 \mathrm{nM}\left[{ }^{125} \mathrm{I}\right]-\mathrm{PTA}-\mathrm{OH}$ in the presence of various concentrations of ONO-11120(O), STA $(\bigcirc)$, U-46619 $(\Delta)$ and prostaglandin $\mathrm{D}_{2}\left(\mathrm{PGD}_{2}\right.$; $\Delta)$. Incubation was carried out at $37^{\circ} \mathrm{C}$ for $20 \mathrm{~min}$. $\mathrm{PGD}_{2}$, $50 \mathrm{nM}$, was added to a reaction with $\mathrm{STA}_{2}$ or U-46619 to prevent aggregation caused by these agents during assay. $\mathrm{PGD}_{2}$ had by itself no effect on [ $\left.{ }^{125} \mathrm{I}\right]-\mathrm{PTA}-\mathrm{OH}$ binding to platelets. The specific binding was obtained by subtracting non-specific binding obtained with $20 \mu \mathrm{M}$ ONO-11120 from each total binding. Mean values are shown, and s.e.mean is shown by a vertical line when it exceeds the size of a symbol $(n=5$, ONO-11120; $n=4$, STA 2 ; $n=3$, $\mathrm{U}-46619 ; n=5, \mathrm{PGD}_{2}$ ). 


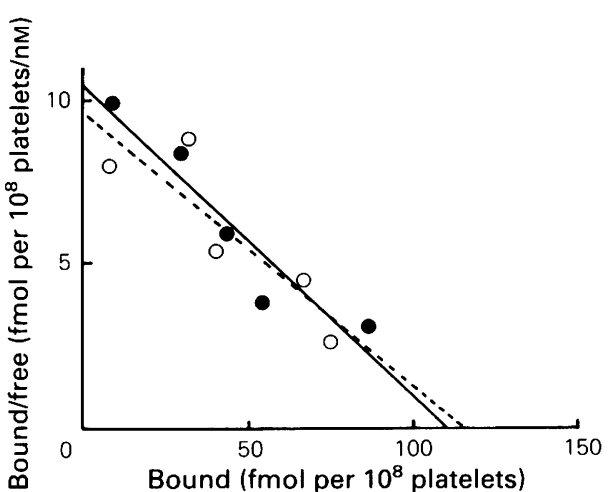

Figure 5 Scatchard plots of the specific $\left[{ }^{125} \mathrm{I}\right]-\mathrm{PTA}-\mathrm{OH}$ binding to washed dog platelets in the presence and absence of adrenaline. Washed dog platelets, $10^{8}$, were incubated with $0.1 \mathrm{nM}\left[{ }^{125} \mathrm{I}\right]-\mathrm{PTA}-\mathrm{OH}$ and various concentrations of ONO-11120 in the presence $(O)$ and absence (O) of $5 \mu \mathrm{M}$ adrenaline at $37^{\circ} \mathrm{C}$ for $20 \mathrm{~min}$. The specific binding was determined as described. A typical result of four similar experiments is shown.
,Binding of [ $\left.{ }^{125} I\right]-P T A-O H$ to platelets of other species

The nature and specificity of $\left[{ }^{125} \mathrm{I}\right]-\mathrm{PTA}-\mathrm{OH}$ binding described above suggested that $\left[{ }^{125} \mathrm{I}\right]-\mathrm{PTA}-\mathrm{OH}$ bound to a putative $\mathbf{T X A}_{2}$-receptor on human platelets. To corroborate this further, we carried out similar binding studies on platelets of other species, namely dog and rabbit, since platelets of these species vary in their responsiveness to several TXA $_{2}$ analogues including pinane thromboxane analogues (Burke et al. 1983; Anderson \& MacIntyre, 1982; see below). When [ $\left.{ }^{125} \mathrm{I}\right]-$ PTA-OH binding was studied with various numbers of platelets from dog and rabbit, specific binding was only observed in dog platelets, which linearly increased with the number of platelets. Significant specific binding was not observed in rabbit platelets even with $2 \times 10^{8}$ platelets (Figure 2). The binding activity in dog platelets was further studied by Scatchard analysis. Sine dog platelets acquire responsiveness to arachidonic acid and $\mathrm{TXA}_{2}$ mimetics only after adrenaline treatment (Johnson et al., 1979), we performed a Scatchard analysis before (control) and after


Figure 6 Effects of ONO-11120 (ONO) on arachidonate (AA)-induced aggregation of human (a), dog (b) and rabbit (c) platelets. Aggregation was induced by adding arachidonic acid at $0.8,0.4$ and $0.5 \mathrm{~mm}$ to platelet-rich plasma obtained from man, dog and rabbit, respectively. ONO-11120 was added 1 min prior to the addition of arachidonic acid at the final concentrations of $0.5 \mu \mathrm{M}$ to human platelets and $5 \mu \mathrm{M}$ to dog and rabbit platelets. Adrenaline (Ad) was added to the dog platelets 2 min prior to aggregation at a final concentrations of $5 \mu \mathrm{M}$. Typical records of at least 5 experiments are shown. 
treatment with $5 \mu \mathrm{M}$ adrenaline. A typical result of the analysis is shown in Figure 5. A single population of binding activity was found under both conditions, and the plots for the control and the adrenaline-treated platelets almost overlapped each other. The $K_{\mathrm{D}}$ and $B_{\max }$ values calculated for the control platelets from three samples were $12.4 \pm 1.0 \mathrm{nM}$ and $112 \pm 18 \mathrm{fmol}$ per $10^{8}$ platelets $(680 \pm 110$ sites per platelet), respectively. These values were not significantly different from the $K_{\mathrm{D}}$ and $B_{\max }$ obtained for adrenaline-treated platelets from the same three samples; the $K_{\mathrm{D}}$ being $12.1 \pm 0.4 \mathrm{nM}$ and $B_{\max }, 107 \pm 7 \mathrm{fmol}$ per $10^{8}$ platelets (647 \pm 42 sites per platelet). Hill coefficients $(n)$ of the binding were 1.008 and 0.996 in the absence and presence of adrenaline, respectively, indicating a single class of binding sites without any cooperativity.

\section{Antiaggregatory action of $\mathrm{ONO}-11120$ on platelets of different species}

Since specific binding of $\left[{ }^{125} \mathrm{I}\right]-\mathrm{PTA}-\mathrm{OH}$ was detected on human and dog platelets but not on rabbit platelets, we compared the antiaggregatory potency of ONO11120 on arachidonic acid-induced aggregation of platelets of these species. Arachidonic acid caused irreversible aggregation of human platelets at $0.7-1.0 \mathrm{~mm}$ and that of rabbit platelets at $0.3-0.5 \mathrm{mM}$. As already found by other investigators (Johnson et al., 1979; Burke et al., 1983), dog platelets were not aggregated by arachidonic acid alone up to $1 \mathrm{mM}$, but, when treated with adrenaline, they showed irreversible aggregation around $0.5 \mathrm{mM}$ arachidonic acid. We, therefore, examined the inhibitory effect of ONO11120 on irreversible aggregation caused by minimal concentrations of arachidonic acid, e.g., $0.8,0.4$ and $0.5 \mathrm{~mm}$ for human, rabbit and adrenaline-treated dog platelets, respectively. As shown in Figure 6, 0.5 $\mu \mathrm{M}$ ONO-11120 blocked completely arachidonic acid-induced aggregation of human platelets, while with $5 \mu \mathrm{m}$ ONO-11120 no suppression of aggregation of rabbit platelets was observed. However, $5 \mu \mathrm{M}$ ONO-11120 almost completely blocked arachidonic acid-induced aggregation of dog platelets pretreated with adrenaline. The different responsiveness of rabbit platelets to ONO-11120 was further revealed and quantified by the use of STA $\mathrm{A}_{2}$ as an aggregating agent. STA $\mathrm{A}_{2}$ caused aggregation of human platelets with a threshold concentration of around $1.0 \mu \mathrm{M}$ and full aggregation was evoked with 2 to $4 \mu \mathrm{M}$; the mean $\mathrm{EC}_{50}$ value was $1.75 \pm 0.28 \mu \mathrm{M}(n=4)$. In contrast, around $5 \mu \mathrm{M} \mathrm{STA} \mathrm{S}_{2}$ was needed to initiate aggregation of rabbit platelets, and about $20 \mu \mathrm{M}$ for full aggregation; the mean $\mathrm{EC}_{50}$ value was $8.17 \pm 2.17 \mu \mathrm{M}(n=3)$. Thus, sensitivity to $\mathrm{STA}_{2}$ was significantly different between platelets of man and rabbit $(P<0.05$, Tukey's method) (Figure 7a). On the basis of these results, the inhibitory action of ONO-11120 was examined against irreversible full

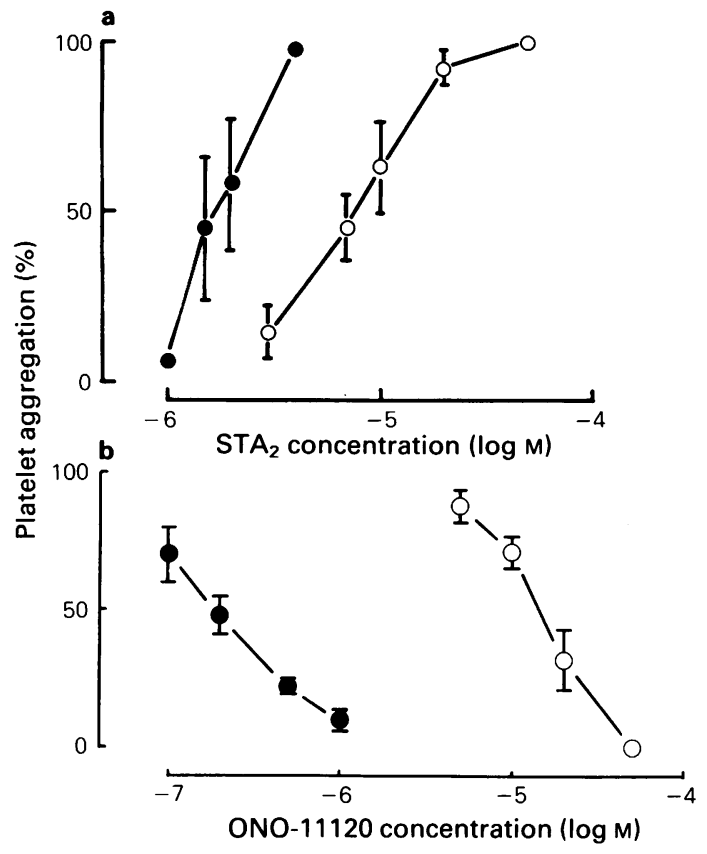

Figure 7 (a) Concentration-effect curves for $\mathrm{STA}_{2}$ in aggregation of platelets from man and rabbits. STA $\mathrm{A}_{2}$ was added to platelet-rich plasma (PRP) obtained from man $(O)$ and rabbit $(O)$, and aggregation was monitored as described in Methods. (b) Concentration-inhibition

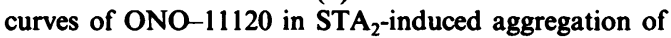
platelets from man and rabbits. ONO-11120 was added to PRP from man (O) and rabbit (O) $1 \mathrm{~min}$ prior to the addition of the minimal concentrations of STA $_{2}$ needed to cause irreversible full aggregation ( 2 to $4 \mu \mathrm{M}$ for human PRP and $20 \mu \mathrm{M}$ for rabbit PRP). Aggregation was monitored as described. Mean values are shown, and s.e.mean is shown by a vertical line when it exceeds the size of a symbol. $n=4$ for human and $n=3$ for rabbit platelets in both (a) and (b).

aggregation induced by 2 to $4 \mu \mathrm{M} \mathrm{STA}_{2}$ for human platelets and $20 \mu \mathrm{M} \mathrm{STA}_{2}$ for rabbit platelets. As shown in Figure $7 \mathrm{~b}$, ONO-11120 inhibited STA ${ }_{2}^{-}$ induced human platelet aggregation potently with an $\mathrm{IC}_{50}$ of $0.16 \pm 0.03 \mu \mathrm{M}(n=4)$. In contrast, about 100 fold this concentration was needed for this compound to inhibit $\mathrm{STA}_{2}$-induced aggregation of rabbit platelets; the $\mathrm{IC}_{50}$ being $16 \pm 3.0 \mu \mathrm{M}(n=3)(P<0.01$, Tukey's method).

\section{Discussion}

[ $\left.{ }^{125} \mathrm{I}\right]-\mathrm{PTA}-\mathrm{OH}$ used as a radioligand for a putative thromboxane receptor in this study is an iodination product of the hydroxy derivative of ONO-11120. 
Insertion of ${ }^{125} I$ to the phenol group of prostanoid analogues and their potential use as radioligands was first suggested by Mais et al. (1984). They further compared the biological activities of $\left[{ }^{125} \mathrm{I}\right]-\mathrm{PTA}-\mathrm{OH}$, PTA-OH and ONO-11120, and found that iodination did not affect its biological activity (Mais et al., 1985a,b). Antiaggregatory activity similar to ONO11120 was found for $\left.{ }^{125} \mathrm{I}\right]-\mathrm{PTA}-\mathrm{OH}$ on human platelets (Mais et al., 1985a). On the basis of these results, we used $\left[{ }^{12 j} \mathrm{I}\right]-\mathrm{PTA}-\mathrm{OH}$ as a radioligand and ONO-11120 as a displacing agent in this study, and found specific binding which appeared to represent binding to a thromboxane receptor on human platelets. Scatchard analysis of our binding studies showed a single class of binding with a $K_{\mathrm{D}}$ of $22 \mathrm{nM}$. This $K_{\mathrm{D}}$ value is more than 10 fold lower than the $\mathrm{IC}_{50}$ of this compound required to inhibit platelet aggregation. This discrepancy, however, may be due to differences in experimental conditions employed in each study; the aggregation study was performed in platelet-rich plasma where most of the antagonist may be bound to plasma proteins in the mixture.

Three groups of investigators have described binding studies for a thromboxane receptor using different radioligands. Hung et al. (1983) used [ $\left.{ }^{3} \mathrm{H}\right]$-13-azaprostanoic acid and found two classes of binding activities on human platelet membrane; one with a $K_{\mathrm{D}}$ of about $100 \mathrm{nM}$ and the other with a $K_{\mathrm{D}}$ of $3.5 \mu \mathrm{M}$. Armstrong et al. (1983) used $\left[{ }^{3} \mathrm{H}\right]-15(\mathrm{~s})-9,11-$ epoxymethano$\mathrm{PGH}_{2}$ and found that $50 \%$ binding was achieved at $77 \mathrm{nM}$. Halushka et al. (1985) used [ [ $\left.{ }^{125} \mathrm{I}\right]-$ cis-APO and described a single class of binding with a $K_{\mathrm{D}}$ value of $1.48 \mu \mathrm{M}$. Thus, our study using [ $\left.{ }^{125} \mathrm{I}\right]-\mathrm{PTA}-\mathrm{OH}$ agrees with the results of Halushka et al. (1985) in that TXA receptor binding on human platelets is of a single class, and has revealed that $\left[{ }^{125} \mathrm{I}\right]-\mathrm{PTA}-\mathrm{OH}$ has about a two orders of magnitude higher affinity to the thromboxane receptor. than $\left.{ }^{125} \mathrm{I}\right]$-cis-APO. Armstrong et al. (1983) analysed further the binding of both the active $(15(S))$ and inactive $(15(R))$ epimers of $\left[{ }^{3} \mathrm{H}\right]-9,11$ epoxymethano-PGH ${ }_{2}$ to human platelets and found that each epimer bound to different binding sites. Their conclusion was that binding of $15(R)$ epimer was not physiological. This problem, however, seemed not to occur in the case of $\left.{ }^{125} \mathrm{I}\right]-\mathrm{PTA}-\mathrm{OH}$, since a recent study by Mais et al. (1985b) showed that both 15epimers of iodinated PTA-OH elicited equal activities on human platelets. The $B_{\max }$ value found in this study was about $390 \mathrm{fmol}$ per $10^{8}$ platelets i.e. 2,300 binding sites per platelet, and was similar to that obtained by Armstrong et al. (1983) on human platelets with $\left[{ }^{3} \mathrm{H}\right]-$ 15(s)-9,11-epoxymethano- $\mathrm{PGH}_{2}$ (their value was 1,700 sites per platelet). This density was several times more than that found for the $\mathrm{PGD}_{2}$ receptor on human platelets (Siegl et al., 1979; Cooper \& Ahern, 1979).

The specificity of [ ${ }^{125}$ I]-PTA-OH binding was investigated by examining its displacement by several TXA ${ }_{2}$ analogues and prostaglandins. Thromboxane antagonists and agonists such as ONO-11120, STA and U-46619 effectively displaced [ $\left.{ }^{125} \mathrm{I}\right]-\mathrm{PTA}-\mathrm{OH}$ binding to human platelets in this order; the $\mathrm{IC}_{50}$ values were 17, 54 and $120 \mathrm{nM}$, respectively. Since Mais et al. (1985a) found that U-46619 was a more potent aggregating agent than STA $_{2}$ of human platelets (we also found that U-46619 was as potent as STA ST $_{2}$, the observed order of displacing potency does not seem to fit with the biological activity. The reason for this discrepancy was not investigated in the present study but could be explained in several ways. Armstrong $e t$ al. (1985) found that CTA ${ }_{2}$ and PTA $\mathrm{P}_{2}$ increased the intracellular level of adenosine $3^{\prime}: 5^{\prime}$-cyclic monophosphate (cyclic AMP) and suggested that these analogues act on both a thromboxane receptor and an inhibitory receptor $\left(\mathrm{PGI}_{2}\right.$ or $\mathrm{PGD}_{2}$ receptor) on platelets to cancel out each action. Since $\mathrm{STA}_{2}$ has a structural similarity to these analogues, it may also interact with an inhibitory receptor on platelets. Another possible explanation concerns the efficacy of transduction. Since the agonist response is dependent on both the efficacy and affinity of the compound under study, STA $\mathrm{A}_{2}$ may have a lower efficacy than U46619. Alternatively, it may be explained simply by differences in binding capacity to serum proteins between the two compounds. PGD $_{2}$ displaced about $70 \%$ of the bound radioactivity at a concentration of $10 \mu \mathrm{M}$ in the present study, whereas such displacement was not observed in another study (Armstrong et al., 1983). The reason for this discrepancy was not identified.

One of the criteria necessary to identify the binding activity of a radioligand as a physiologically relevant receptor is correlation of distribution of binding with that of biological activity of the compound between tissues and species. We investigated any such correlation using platelets of different species; differences in the responsiveness of platelets to TXA $_{2}$ analogues between species, especially rabbit platelets, has already been observed by several groups (Anderson \& MacIntyre, 1982; Burke et al., 1983). In the present study we examined the sensitivity of human, dog and rabbit platelets to inhibition by ONO-11120 of arachidonic acid-induced aggregation. Arachidonic acid caused aggregation at almost the same concentrations in platelets from these species (dog platelets in the presence of adrenaline). The addition of 0.5 and $5 \mu \mathrm{M}$ ONO-11120 completely suppressed the aggregation of human and dog platelets, respectively, whereas no effect was found in rabbit platelets (Figure 6). Thus, rabbit platelets were insensitive to ONO-11120. We further found that platelets of this species were 10 times less sensitive to $\mathrm{STA}_{2}$ (Figure 7a). To aggregate rabbit platelets $20 \mu \mathrm{M} S T A_{2}$ was required in comparison with $2 \mu \mathrm{M}$ in the case of human platelets. When a similar aggregation response was evoked by $\mathrm{STA}_{2}$ in 
platelets of these species and the suppressive effect of ONO-11120 was compared, rabbit platelets were again found to be about 100 times less sensitive to ONO-11120 (Figure 7b). Consistent with these findings, no significant binding of $\left.{ }^{125} \mathrm{I}\right]-\mathrm{PTA}-\mathrm{OH}$ was found on rabbit platelets (Figure 2). Raising the radioligand concentration to $10 \mathrm{nM}$ did not reveal any specific binding on rabbit platelets, since enormous non-specific binding was observed under such conditions, usually 330,000 c.p.m. per $10^{8}$ platelets, this presumably prevented the detection of the small amount of specific binding expected (unpublished observations). In contrast to these findings with rabbit platelets, we found significant binding of the ligand to dog platelets. Dog platelets are also of interest in terms of thromboxane binding sites, since the platelets of this species respond to a thromboxane agonist and arachidonic acid only after adrenaline treatment (Johnson et al., 1979). Although this effect of adrenaline has recently been presumed to be due to suppression of adenylate cyclase via $\alpha$-adrenoceptors (Johnson et al., 1980), there is a possibility that it evokes mobilization of thromboxane receptors on the platelet surface, as demonstrated for fibrinogen receptors (Plow \& Mar-

\section{References}

ANDERSON, L. \& MACINTYRE, D.E. (1982). Differences between the thromboxane $A_{2}$ receptors on rabbit and human platelets. Br. J. Pharmac., 77, 546P.

ARMSTRONG, R.A., JONES, R.L. \& WILSON, N.H. (1983). Ligand binding to thromboxane receptors on human platelets: correlation with biological activity. $\mathrm{Br} . \mathrm{J}$. Pharmac., 79, 953-964.

ARMSTRONG, R.A., JONES, R.L., PEESAPATI, V., WILL, S.G. \& WILSON, N.H. (1985). Competitive antagonism at thromboxane receptors in human platelets. Br. J. Pharmac., 84, 595-607.

BHAGWAT, S.S., HAMANN, P.R., STILL, W.C., BUNTING, S. \& FITZPATRICK, F.A. (1985). Synthesis and structure of the platelet aggregation factor thromboxane $A_{2}$. Nature, 315, 511-513.

BUNDY, G.L. (1975). Synthesis of prostaglandin endoperoxide analogs. Tetrahedron Lett., 1957-1960.

BURKE, S.E., LEFER, A.M., NICOLAOU, K.C., SMITH, G.M. \& SMITH, J.B. (1983). Responsiveness of platelets and coronary arteries from different species to synthetic thromboxane and prostaglandin endoperoxide analogues. Br. J. Pharmac., 78, 287-292.

COLEMAN, R.A., COLLINGTON, E.W., GEISOW, H.P., HORNBY, E.J., HUMPHREY, P.P.A., KENNEDY, I., LEVY, G.P., LUMLEY, P., MCCABE, P.J. \& WALLIS, C.J. (1981). AH 19437 , a specific thromboxane receptor blocking agent? Br. J. Pharmac., 72, 524P-525P.

COOPER, B. \& AHERN, D. (1979). Characterization of the platelet prostaglandin $\mathrm{D}_{2}$ receptor. J. clin. Invest., 64, 586-590.

COREY, E.J., NARASAKA, K. \& SHIBAZAKI, M. (1976). A direct stereo-controlled total synthesis of the 9,11-azo guerie, 1980). Our findings, however, showed no change in the $K_{\mathrm{D}}$ and $B_{\max }$ of [ ${ }^{125} \mathrm{I}$ ]-PTA-OH binding to dog platelets before and after adrenaline treatment.

In conclusion, we have found specific binding activity of $\left.{ }^{125} \mathrm{I}\right]-\mathrm{PTA}-\mathrm{OH}$ on washed human as well as dog platelets. Based on a comparison with biological activity, we suggest this binding activity represents a $\mathrm{TXA}_{2}$ receptor on platelets. Analyses of this binding in different species have revealed that there is some difference in the ligand-binding structure of the receptor on platelets of different species. Such differences should be borne in mind in the pharmacological evaluation of a thromboxane antagonist such as ONO-11120 in animal experiments.

We gratefully acknowledge the supply of PTA-OH, ONO11120 and STA $A_{2}$ from Dr N. Hamanaka of the Ono Central Institute, and of U-46619 from Dr J.E. Pike of the Upjohn Company. This work was supported in part by grants in aid for scientific research from the Ministry of Education, Science and Culture of Japan (no. 6057013, no. 60214020, no. 60570556), and grants from Suzuken Foundation and the Japanese Foundation on Metabolism and Diseases.

analogue of the prostaglandin endoperoxide, $\mathrm{PGH}_{2} . \mathrm{J}$. Am. chem. Soc., 98, 6417-6418.

HALUSHKA, P.V., MACDERMOT, J., KNAPP, D.R., ELLER, T., SAUSSY, D.L. JR, MAIS, D., BLAIR, I.A. \& DOLLERY, C.T. (1985). A novel approach for the study of thromboxane $A_{2}$ and prostaglandin $H_{2}$ receptors using an $I^{125}$. labelled ligand. Biochem. Pharmac., 34, 1165-1170.

HAMBERG, M., SVENSSON, J. \& SAMUELSSON, B. (1975). Thromboxanes: a new group of biologically active compounds derived from prostaglandin endoperoxides. Proc. natn. Acad. Sci. U.S.A., 72, 2994-2998.

HUNG, S.C., GHALI, N.I., VENTON, D.L. \& LE BRETON, G.C. (1983). Specific binding of the thromboxane $A_{2}$ antagonist 13-azaprostanoic acid to human platelet membranes. Biochim. biophys. Acta, 728, 171-178.

JONES, R.L., PEESAPATI, V. \& WILSON, N.H. (1982). Antagonism of the thromboxane-sensitive contractile systems of the rabbit aorta, dog saphenous vein and guinea-pig trachea. Br. J. Pharmac., 76, 423-438.

JOHNSON, G.J., LEIS, L.A., RAO, G.H.R. \& WHITE, J.G. (1979). Arachidonate-induced platelet aggregation in the dog. Throm. Res., 14, 147-154.

JOHNSON, G.J., RAO, G.H.R., LEIS, L.A. \& WHITE, J.G. (1980). Effect of agents that alter cyclic AMP on archidonateinduced platelet aggregation in the dog. Blood, 55, $722-729$.

KATSURA, M., MIYAMOTO, T., HAMANAKA, N., KONDO, K., TERADA, T., OHGAKI, Y., KAWASAKI, A. \& TSUBOSHIMA, M. (1983). In vitro and in vivo effects of new powerful thromboxane antagonists (3-alkylamino pinane derivatives). Adv. in Prostaglandin, Thromboxane \& Leukotriene Res., 11, 351-357. 
LE BRETON, G.C., VENTON, D.L., ENKE, S.E. \& HALUSHKA, P.V. (1979). 13-Azaprostanoic acid: a specific antagonist of the human blood platelet thromboxane/endoperoxide receptor. Proc. natn. Acad. Sci. U.S.A., 76, 4097-4101.

LEFER, A.M., SMITH, E.F., III, ARAKI, H., SMITH, J.B., AHARONY, D., CLAREMON, D.A., MAGOLDA, R.L. \& NICOLAOU, K.C. (1980). Dissociation of vasoconstrictor and platelet aggregatory activities of thromboxane by cabocyclic thromboxane $\mathbf{A}_{2}$, a stable analog of thromboxane $\mathrm{A}_{2}$. Proc. natn. Acad. Sci. U.S.A., 77, 1706-1710.

MAIS, D., KNAPP, D., HALUSHKA, P., BALLARD, K. \& HAMANAKA, N. (1984). Synthesis of thromboxane receptor antagonists with the potential to radiolabel with ${ }^{12} \mathrm{I}$. Tetrahedron Lett., 25, 4207-4210.

MAIS, D.E., SAUSSY, D.L. JR., CHAIKHOUNI, A., KOCHEL, P.J., KNAPP, D.R., HAMANAKA, N. \& HALUSHKA, P.V. (1985a). Pharmacologic characterization of human and canine thromboxane $A_{2}$ /prostaglandin $H_{2}$ receptors in platelets and blood vessels: evidence for different receptors. J. Pharmac. exp. Ther., 233, 418-424.

MAIS, D.E., DUNLAP, C., HAMANAKA, N. \& HALUSHKA, P.V. (1985b). Further studies on the effects of epimers of thromboxane $\mathrm{A}_{2}$ antagonists on platelets and veins. Eur. J. Pharmac., 111, 125-128.

NICOLAOU, K.C., MAGOLDA, R.L., SMITH, J.B., AHARONY, D., SMITH, E.F. \& LEFER, A.M. (1979). Synthesis and biological properties of pinane-thromboxane $A_{2}$, a selec- tive inhibitor of coronary artery constriction, platelet aggregation, and thromboxane formation. Proc. natn. Acad. Sci. U.S.A., 76, 2566-2570.

PARISE, L.V., VENTON, D.L. \& LE BRETON, G.C. (1984). Arachidonic acid-induced platelet aggregation is mediated by a thromboxane $A_{2}$ /prostaglandin $\mathrm{H}_{2}$ receptor interaction. J. Pharmac. exp. Ther., 228, 240-244.

PLOW, E.F. \& MARGUERIE, G.A. (1980). Induction of the fibrinogen receptor on human platelets by epinephrine and the combination of epinephrine and ADP. J. biol. Chem., 255, 10971-10977.

SIEGL, A.M., SMITH, J.B. \& SILVER, M.J. (1979). Specific binding sites for prostaglandin $\mathrm{D}_{2}$ on human platelets. Biochem. biophys. Res. Commun., 90, 291-296.

SVENSSON, J., HAMBERG, M. \& SAMUELSSON, B. (1976). On the formation and effects of thromboxane $\mathrm{A}_{2}$ in human platelets. Acta physiol. scand., 98, 285-294.

SVENSSON, J., STRANDBERG, K., TUVEMO, T. \& HAMBERG, M. (1977). Thromboxane $A_{2}$ : effects on airway and vascular smooth muscle. Prostaglandins, 14, 425-436.

YOSHIMOTO, T., YAMAMOTO, S., OKUMA, M. \& HAYAISHI, O. (1977). Solubilization and resolution of thromboxane synthesizing system from microsomes of bovine blood platelets. J. biol. Chem., 252, 5871-5874.

WALLENSTEIN, S., ZUCKER, C.L. \& FLEISS, J.L. (1980). Some statistical methods useful in circulation research. Circulation Res., 47, 1-9.

(Received August 29, 1985.

Revised February 4, 1986. Accepted February 20, 1986.) 